\title{
CUESTIÓN DE FRONTERA El desecho como resto y valor
}

\author{
Question of Border
}

The Waste as Rest and Value

Julia Cortese | juliacortese@hotmail.com

Facultad de Bellas Artes Universidad Nacional de La Plata

Argentina

Reseña a Nicolas Bourriaud (2015). La exforma. Ciudad Autónoma de Buenos Aires, Argentina: Adriana Hidalgo, 146 páginas

Recibido: 2/2/2018 Aceptado: 11/5/2018

\section{RESUMEN}

La exforma es un ensayo de Nicolas Bourriaud que analiza aquellas producciones que tienen lugar en la frontera entre lo excluido y lo establecido. A la luz del arte contemporáneo, el autor recorre tiempos o momentos en la historia del arte y del pensamiento, intelectuales, corrientes, artistas, en suma, movimientos que transitaron lo exformal al poner en crisis el Ideal.

\section{PALABRAS CLAVE}

Arte contemporáneo; exforma; frontera

\begin{abstract}
La exforma [The exform] is an essay by Nicolas Bourriaud that analyses those productions which take place on the borderline between the excluded and the established. In the light of contemporary art, the author goes through times or moments in the history of art and thought as well as the intellectuals, currrents, artists, in short, movements that transited the exformal to put the ideal in crisis.
\end{abstract}

\section{KEYWORDS}

Contemporary art; exformal; frontier 
Nicolas Bourriaud es escritor, curador y crítico de arte francés. Fue curador del Pabellón Francés de la Bienal de Venecia de 1990, director artístico de la Bienal de Lyon en el año 2005, curador del Tate Britain de Londres -en el que organizó la Cuarta Trienal en 2009-, entre otras actividades. Autor de novelas y de ensayos, como Postproducción (2004), Estética relacional (2006) y Radicante (2009) sus producciones han generado gran impacto en el mundo del arte y de los estudios culturales.

Mientras que el capitalismo utopiza un mundo en el que las mercancías circulan sin roces, aquello que nos rodeaba aparece en forma de exceso, como productos perecederos, como meros residuos. Crece lo desechable, entendido como inútil o como no asimilable. En esa fricción entre lo excluido y lo establecido toma lugar lo exformal: término fronterizo entre la disidencia y el poder que presenta y desarrolla el autor en su ensayo.

La Revolución Industrial trazó vínculos entre el centro y la periferia, los cuales se presentan en el libro como aquellos que surgen de esa fuerza centrífuga de exclusión que rechazó categóricamente ciertos objetos, signos e imágenes. A medida que desarrolla el escrito, Bourriaud recorre tiempos o momentos en la historia del arte y del pensamiento, intelectuales, corrientes, artistas; en suma, movimientos que atravesaron, de algún modo, el camino de la exforma al problematizar el Ideal. Modernidad, vanguardias, conceptualismo, minimalismo, Courbet, Marx, Freud, Lacan, Althusser, Benjamin y Borges dialogan en una trama que, a la luz de lo propuesto por el arte contemporáneo, intentará analizar los efectos de esas mutaciones.

«El gesto de la expulsión y el residuo que se deriva de este (o sea: el punto de la aparición de una exforma) aparecen como un verdadero lazo orgánico entre la estética y la política [...]» (Bourriaud, 2015, p. 11). En una apuesta que iba a marcar su carácter político-artístico, las vanguardias propusieron invertir aquel movimiento centrífugo reciclando los residuos, utilizando aquello que el centro había categorizado como inutilizable.
Al preguntarse si esa fuerza centrípeta aún hoy surte efecto, el autor sostiene que no alcanza para ser artista rechazar en nombre de un ideal, recuperar lo desechado - esto no es igual a sostener que para un artista todo, hasta lo más inadmitido, puede cobrar valor estético-. El derrumbe que vino después allanó el camino de la amnesia, la vanguardia se opacó y la utopía económica se impuso como meta, obligándonos a aprender de nuevo. Así, Bourriaud propone su escrito como parte de ese volver a empezar, pero sin negar la idea de regresar a un algo.

A partir de lo acontecido en la década del sesenta, el autor establece una analogía entre el arte contemporáneo (para el que todo es figurable) y el objeto de curación psicoanalítica (donde lo aparentemente insignificante podría volverse útil). La obra de arte, desde aquel entonces, se iba a medir por su reflexión sobre la norma, como «[...] demostración de la absoluta materialidad del vacío, del azar, de la ideología, del inconsciente, de todo lo que constituye la reserva natural de lo inefable o de lo místico" (Bourriaud, 2015, p. 28).

A sabiendas de que el arte no debe ilustrar la historia, el autor se pregunta, sin embargo, si puede hacer la historia. En el marco de un progreso ligado a la noción de tiempo cronológico, al arte no le cabría más función que la de reflejo o la de ilustración; por lo que hubiese bastado con llegar a aquella verdad que proponía la perspectiva renacentista. «La función histórica, y por lo tanto política, solo adquiere realidad en el escenario abierto de una historia humana puramente contingente; o, $a$ mínima, en la aporía productiva de una oposición entre azar y necesidad» (Bourriaud, 2015, p. 61).

El arte contemporáneo no se nos presenta como una totalidad orgánica, sino como fragmentos que permiten actuar sobre la realidad y transformarla al producir versiones alternativas. «El arte expone el carácter no-definitivo del mundo. Lo disloca, lo recompagina, le devuelve su desorden y poesía» (Bourriaud, 2015, p. 73), mientras que los aparatos ideológicos proponen lo contrario: que el marco 
en el que vivimos es inmutable y definitivo. Su problemática estará en cómo organizar las múltiples temporalidades, una dinámica heterocrónica que se instala evocando una constelación donde el tiempo actúa como metáfora.

Sin embargo, el autor plantea una paradoja: en una época de archivo infinito en que el trayecto y los procesos terminan volviéndose una forma artística, el arte contemporáneo termina por negar la existencia del desecho, dado que nada ni nadie puede considerarse inutilizable, constituyéndose así como resto y valor. Bourriaud abre un camino al sostener que la función social del arte contemporáneo consistirá en reconciliar ambos mundos, otorgándoles un nuevo sentido. 